\title{
DEVELOPMENT CONDITIONS OF POLISH HOUSING MARKET DURING ECONOMIC CRISIS
}

\author{
Ewa Siemińska, Prof. \\ Faculty of Economic Sciences and Management \\ Nicolaus Copernicus University \\ e-mail: ewahsiem@econ.umk.pl
}

Małgorzata Rymarzak, PhD
Faculty of Management
University of Gdansk
e-mail: mrymarzak@wzr.ug.edu.pl

\begin{abstract}
The main purpose of the paper is to present some of the mechanisms connected with the functioning of the Polish housing market, with due regard to demand and supply volatility as well as the changing financial conditions at the time of the global financial crisis of the first decade of the present century. Special attention is given to the financial and legal regulations concerning the housing market, which were introduced in response to the economic downturn.

On the basis of research conducted by the authors, as well as available reports and statistics for 2007-2013, the article will explore market phenomena (the size and pattern of demand, supply and prices on the housing market, and the changes they undergo) on the one hand, and the legal and financial regulatory changes directly affecting them, on the other. It will also study the effects of the implementation of the recommendations made by the Polish Financial Supervision Authority (KNF) by banks in the wake of the global financial crisis. These cause banks to tighten their credit policies and, accordingly, have an impact on their loan portfolios. Information from secondary sources has also been used, notably from the Central Statistical Office (GUS), the KNF, the National Bank of Poland (NBP), as well as the Polish Bank Association (ZBP) and the Credit Information Bureau (BIK). Changes that occurred during the period of economic crisis in the availability of housing have also been examined.
\end{abstract}

Key words: housing market, Poland, mortgage, financial regulation.

JEL Classification: R30, D03, D70.

Citation: Siemińska E., Rymarzak M., 2014, Development conditions of Polish housing market during economic crisis, Real Estate Management and Valuation, vol. 22, no. 4, pp. 68-80.

DOI: $10.2478 /$ remav-2014-0038

\section{Introduction}

The housing market in Poland, like in many other countries, has been through a period of rapid, systemic changes connected with the global economic crisis (SANDERS 2008; COLEMAN et al. 2008; BRUECKNER et al. 2012; KAU et al. 2011; BHARDWAJ, SENGUPTA 2012). Prudential regulations, introduced at both national and supranational levels in response to these changes, as well as numerous solutions of both legal and financial nature, designed to enhance the security and transparency of transactions, form a new business environment for many players in the housing market. Although the Polish economy has, since the beginning of the global financial crisis, been in a reasonably good shape in comparison with other countries, the effects of the crisis can, nevertheless, be felt in many segments of the market when it comes to specific economic parameters. Therefore, an overview of the changes in 
the Polish housing market, including the new regulatory provisions, seems to be an interesting task. Some of these regulations were implemented to meet the requirements of international regulatory bodies, while others were introduced in response to unwanted phenomena occurring in the domestic market. The former include, for instance, the financial regulations related to CRD directives II, III and IV of the European Commission and the Basel Committee, while the latter comprise the recommendations on financing the housing market made by the Polish Financial Supervision Authority (KNF), or the governmental programme of financial support to families buying a flat of their own ("The Family-owned Accommodation Programme"). All these changes, introduced at a time of a global financial downturn, forced many stakeholders in the housing market to take necessary adjustment measures.

The present study will deal in particular with the mechanism of introducing various financial and legal tools as the risk posed to the Polish economy by the global recession increases, as well as accompanying dynamic socio-economic and demographic changes. In every crisis, various types of risk carried by real estate market financing and investments, and the possible effects of such risks, have to be identified and kept in mind. The Polish experience shows that in view of the relatively short history of the real estate and mortgage markets, both have to be monitored closely, while effective instruments are sought to mitigate these risks and raise the economic awareness of the public.

\section{Changes in the Polish housing market}

Since 2008, the Polish economy, like the economies of many other countries, has felt the impact of the turmoil in international financial markets, which is leading to the economic slowdown and reduced demand in many segments of the market.

Poland's economic growth rate in the first decade of the 21st century - positive, but decelerating coupled with poorer development prospects for the nearest future, caused by adverse external conditions, notably the financial problems of many EU economies, weaken the demand in many market segments. The construction industry market is an important and very sensitive sector in every national economy; therefore, it immediately reflects any changes in the business trends (SIEMIŃSKA 2012).

The pace of changes in the supply of apartments in Poland was the greatest between 2007 and 2009, when the number of new apartments offered, new constructions started and building permits issued reached their peak and bottom values in 2007 and 2009, respectively (NYKIEL 2011). The number of new housing projects and building permits has been steadily declining as of recently; in the third quarter of 2013, the two parameters reached their lowest levels since 2004 (Figure 1).

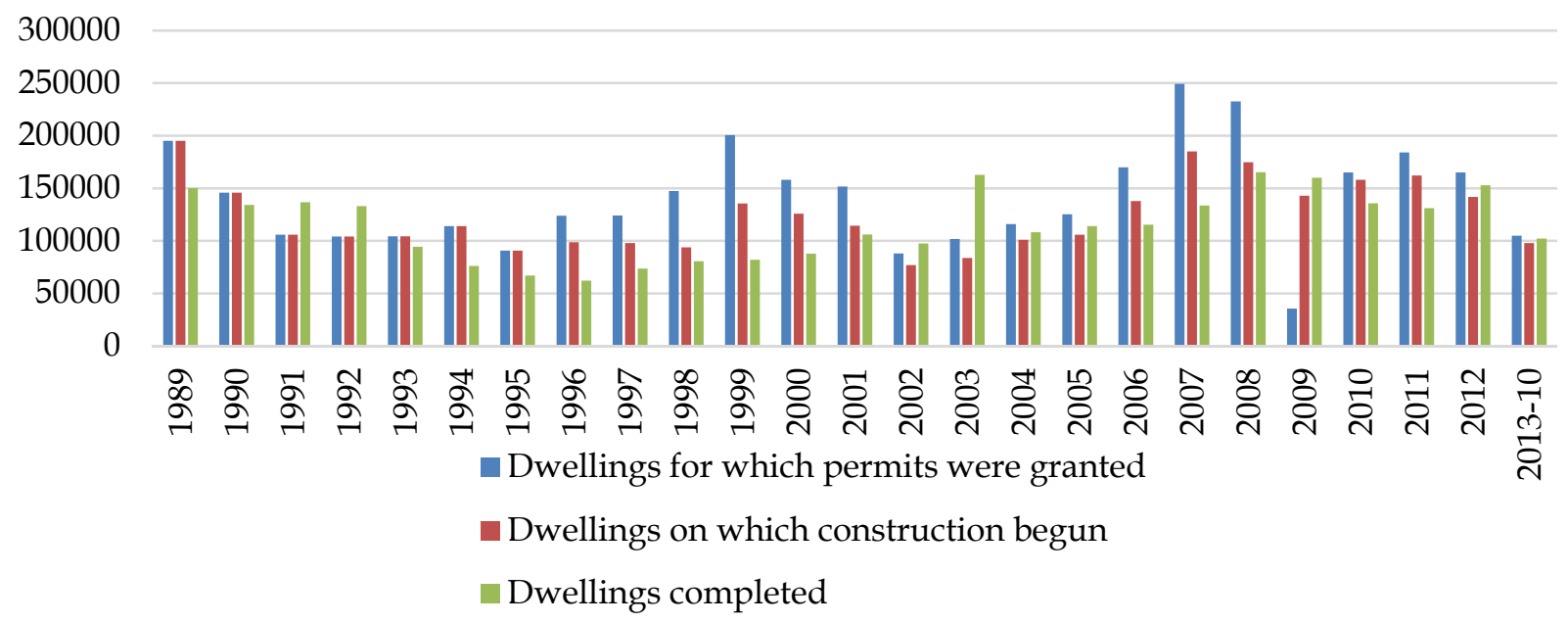

Figure 1. Housing construction in Poland in period between 1989 and 2013. Source: GUS 2013.

The clear decline in the demand for accommodation at the turn of 2008 and 2009, seen through the falling sales and, consequently, prices, was the main reason for the developers' decisions to limit the scale of many of their investment projects or abandon them altogether. This was coupled with a variety of incentives for buyers, the purpose of which was to speed up the disposal of unsold space (SIEMIŃSKA 2011) (Figure 2). 
14000

12000

10000

8000

6000

4000

2000

0
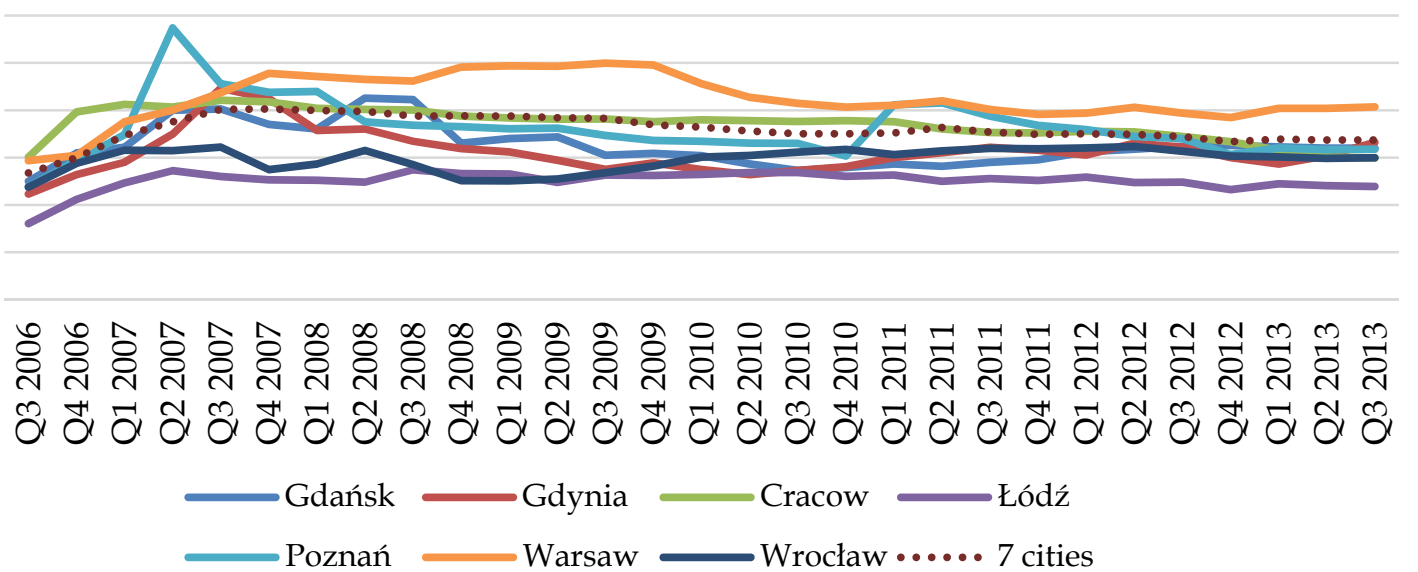

Figure 2. Changes in house prices on the primary market in the largest Polish cities over the years 2006-2013 (PLN per m².). Source: NBP 2013.

The existing overhang of an estimated forty-one thousand unsold apartments dates from this very period, yet it has been decreasing as less new space appears on the market (EY 2014).

After significant price rises for new apartments prior to 2008, in some locations reaching 20-30 per cent, there was a turnaround, with high prices sustained the longest in the Polish capital of Warsaw.

\section{Bank credit offer - volume and pattern}

One of the main causes of the changes in the housing market mentioned above was the dramatic decrease in lending by the banking sector, resulting mainly from the turmoil in the global financial market and deterioration of the socio-economic and demographic situation of the country (FORYŚ 2011; LIS 2012; TROJANEK 2013). As the financial and the real estate markets are strongly interconnected, there is a strong correlation between phenomena occurring in the two markets. This is why a significant deterioration in the Polish banking sector's liquidity in the initial phase of the crisis resulted in stricter credit policies of banks, especially credit rating criteria for both corporate and retail clients. Consequently, the terms of credits also became less favorable. Stricter policies were implemented especially in those sectors of the economy which banks considered to be most risky. At a time of economic downturn, such sectors include the construction industry and property services, i.e. areas closely related to housing (NBP X 2013). Banks perceive the risk involved in the crediting of businesses from these sections of the economy to be higher, as the receivables from them are marked by a higher-than-average problem loan ratio, while constituting a significant proportion of the banks' loan portfolios. The value of the charges made by banks on account of loans granted to businesses from this section has been decreasing since 2013, while the problem loan ratio has not changed much. This suggests that a significant proportion of the credit risk cost connected with problems of businesses from this section has already been accounted for by banks in their financial results (NBP XII 2013).

The authors of the study conducted a survey in 2010 of 39 branch offices of fifteen largest banks on the Polish market, concerning the changes in bank credit policies caused by the global financial crisis. The results confirm that the policies were tightened (according to 82 per cent of the respondents) and identify the following factors as determining the direction of the more rigorous rules that were introduced (SIEMIŃSKA 2011):

1) changes in the economic situation in both the global and domestic markets and the risks involved,

2) decisions of the National Bank of Poland (NBP) and the KNF, affecting the way the banking sector operates,

3) current and anticipated situation in terms of the bank's capital,

4) the degree of competition from other banks.

The survey also revealed that more rigorous criteria were used, especially for new or prospective clients. These included parameters not applied previously, yet with a bearing on the client's creditworthiness, such as the industry in which he/she is employed, type of employment and his/her 
family situation. Moreover, the survey demonstrated that as the number of problem loans in bank portfolios grew, loan applications were verified according to more stringent criteria, and some products were withdrawn from the market altogether (e.g., Swiss franc denominated mortgages). Credit analysis procedures were also made more secure through the application of the following:

1) various databases with information on the prospective client (in Poland, they are held by, among others, Credit Information Bureau - BIK, Business Information Bureau - BIG InfoMonitor, Bank Register of Defaulting Clients),

2) automated data processing systems, i.e. scoring methods, so-called loan calculators or rating models,

3) on-site visits on the premises of the prospective clients to verify the information obtained on both the clients themselves and on the real property to collateralize the loan,

4) value estimates of the property (used as mortgage collateral), with more and more attention paid to the credibility of property valuations.

An important effect of the global financial crisis was the loss of trust in the interbank market, leading to considerable bank rate adjustments and consequently, to a reduction in the funds available for the credit activity of banks. In the Polish market, an extra source of credit risk was the currency pattern of the banks' loan portfolios, in which the Swiss franc prevailed (SIEMIŃSKA, RYMARZAK 2012).

The scale and the changes in mortgage debt level since 2002, when - roughly speaking - such instruments came to be used in Poland, are shown in Figure 3. The significant increase, especially in 2006-2008, was followed by a visible slowdown in new loans, which continues until today.

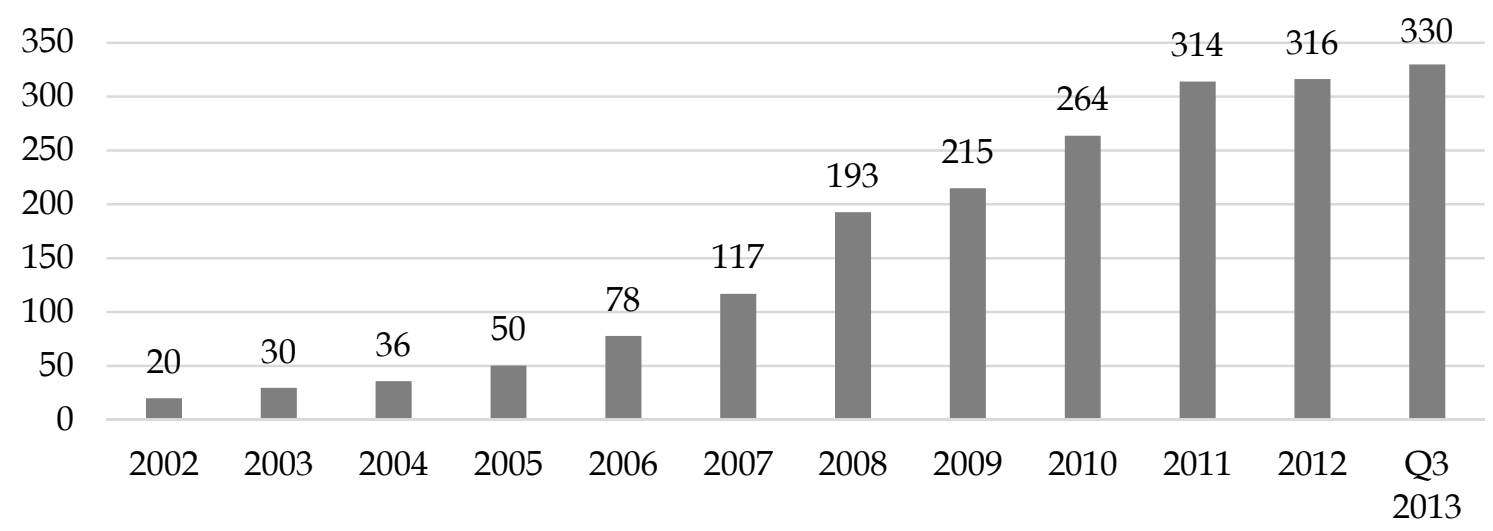

Figure 3. Mortgage debt in 2002-2013 (PLN billion). Source: ZBP 2013.

It is worth noting here, after the European Mortgage Federation, that the level of mortgage debt in Poland - ca. 20\% GDP in 2012 - is relatively low in comparison with the ratios in EU member states, though it stood at only a few per cent at the beginning of the century (Figure 4).

\section{The quality of the mortgage loan portfolio}

As has been noted, the availability and the attractiveness of the banks' loan offer, which are the combined result of a multitude of interdependent factors connected with both the macro- and microenvironment, are of crucial importance to the development of the housing sector. For the safety of the financial system, however, the priority is the quality of the banks' loan portfolios - something so painfully experienced even by some global financial giants. This is why in recent years, many experts have focused their attention on the financial parameters which will help to monitor this quality in a credible way, as it directly affects liquidity and solvency, and consequently, the security of the financial system (SIEMIŃSKA 2013; BOLEAT, ADRIAN 2012; BORGERSEN, GREIBROKK 2012; GAN et al. 2012; GROSSE 2012; KALLAKMAA-KAPSTA, KOLBRE 2013).

These parameters include the proportion of past due housing loans in the total loan volume. In Poland, the amount has doubled from PLN 10 billion in 2010 to PLN 20 billion in 2013 (Figure 5).

A more thorough analysis reveals that the share of so-called lost loans, i.e. not repaid after 90 days from their maturity, in the value of retail housing loans - both PLN and foreign currency denominated - shows an upward trend, which is the result of the natural aging of the portfolio (UKNF 2012; NBP 2012). 
In a comparison of the PLN versus foreign currency housing loan portfolios it should be noted that PLN-denominated loans deteriorated faster, which was mainly due to the decision to convert the foreign currency-denominated problem loans to the national currency. Other causes included the repayment of PLN loans before maturity, as well as the reduced amount of foreign currency loans sold recently, as a result of which their average age is greater than the age of PLN-denominated loans (UKNF 2011; SIEMIŃSKA 2013).

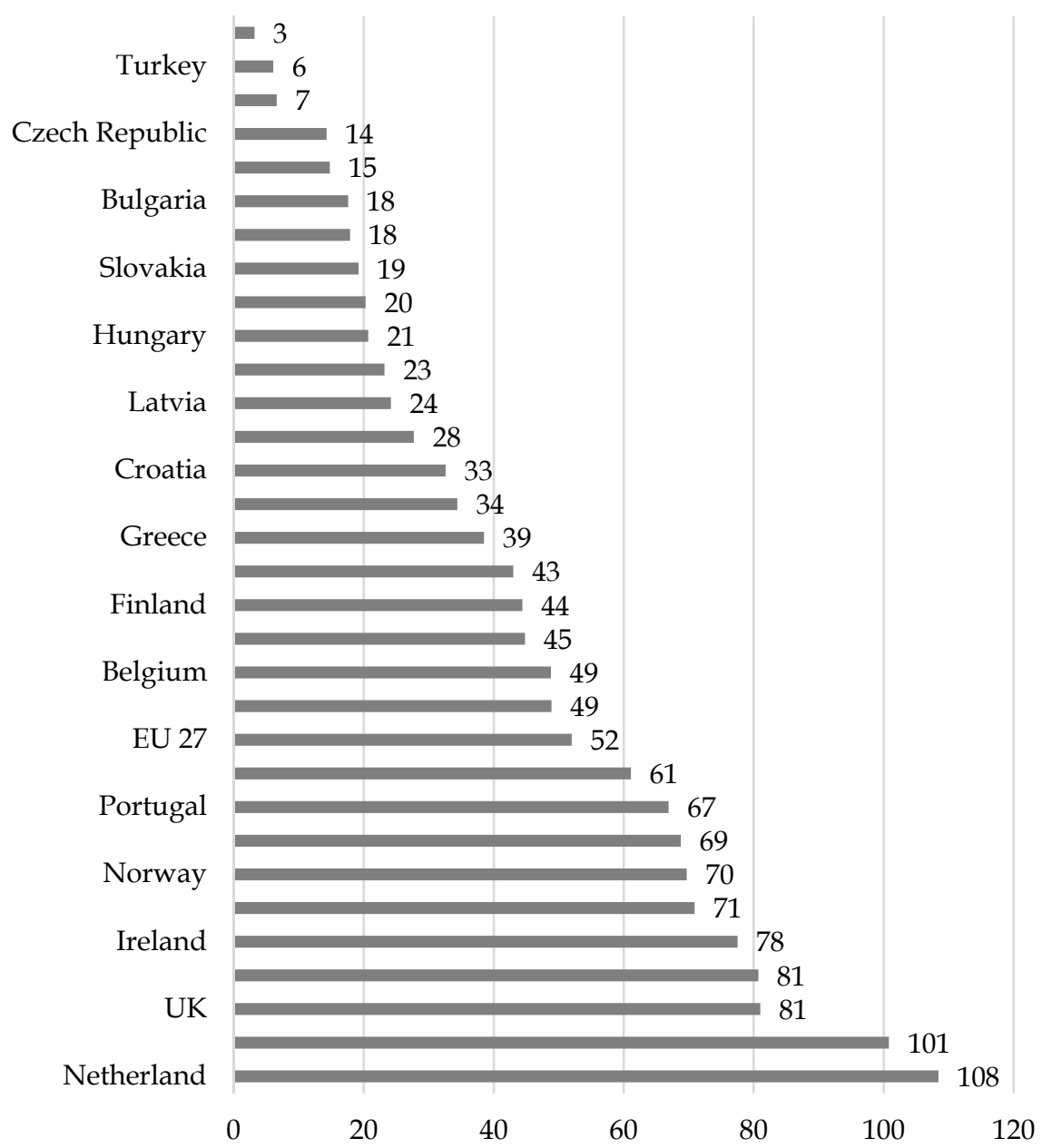

Figure 4. Residential Debt to GDP Ratio (\%) in 2012. Source: EUROPEAN MORTGAGE FEDERATION 2013.

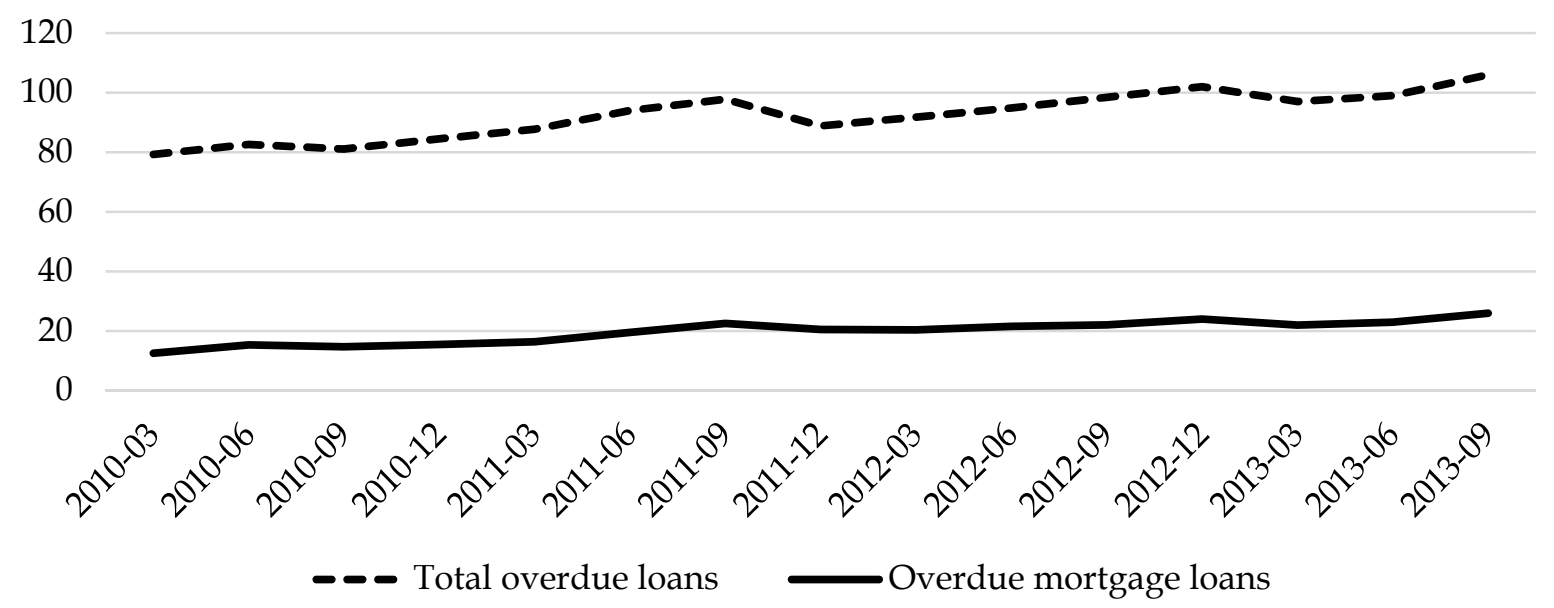

Figure 5. Past due loans versus past due housing loans in 2010-2013 (PLN billion). Source: UKNF IX 2012. 
Furthermore, periodical comparisons (e.g. made by the NBP, BIK and KNF) indicate the relatively poorest performance of loans granted in 2008, i.e. at the height of the investment boom and the openness of the banking system that accompanied it (UKNF 2011). At the same time, it may be observed that mortgage debt deterioration slowed down in 2012, especially in comparison with the preceding year. This was, among other things, caused by PLN depreciation in 2011, and its appreciation the following year.

Another important aspect of the quality of mortgage portfolios, which is indeed a major problem in Poland, is the financing of long-term loan exposures connected with the real estate market with shortterm assets. This lack of symmetry, which has persisted for a considerable period now, is the source of liquidity risk, especially for banks with portfolios in which mortgages prevail (Figure 6).

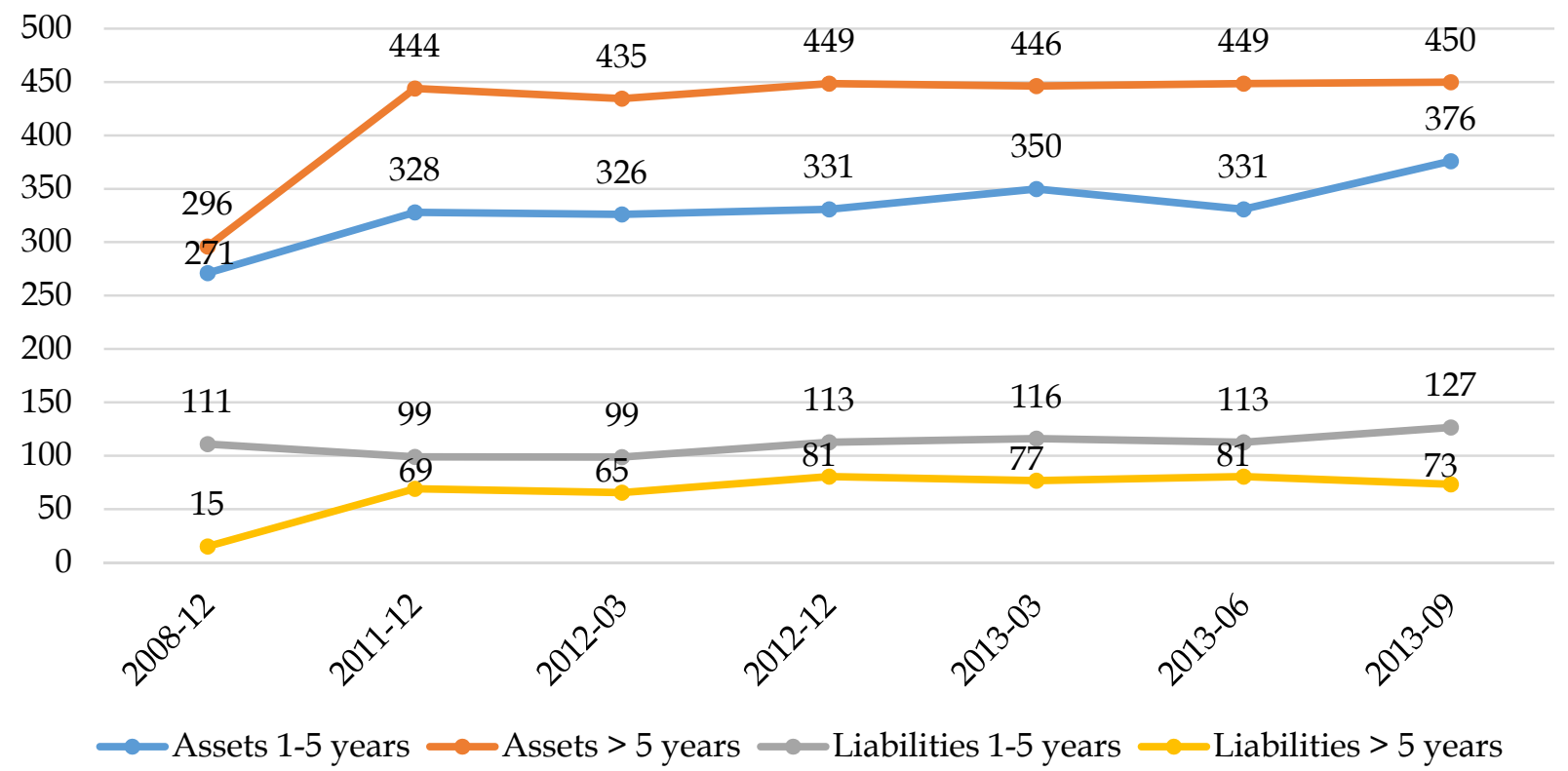

Figure 6. Repayment date pattern of the banking sector in Poland in 2008-2013 (PLN billion). Source: UKNF 2013a; UKNF 2013b; UKNF 2013c.

The identified mismatch of financing sources is made even worse at some banks, whose portfolios are not diversified enough. This is demonstrated by the fact that while the share of housing loans in the banking sector's assets was 7 per cent in 2004, it was as high as 23 per cent in 2013. In such situations, various types of risk cumulate for the bank: firstly, risks connected with the loan repayment ratio, secondly, risks related to the situation in the housing market and, thirdly, the currency and bank rates risks.

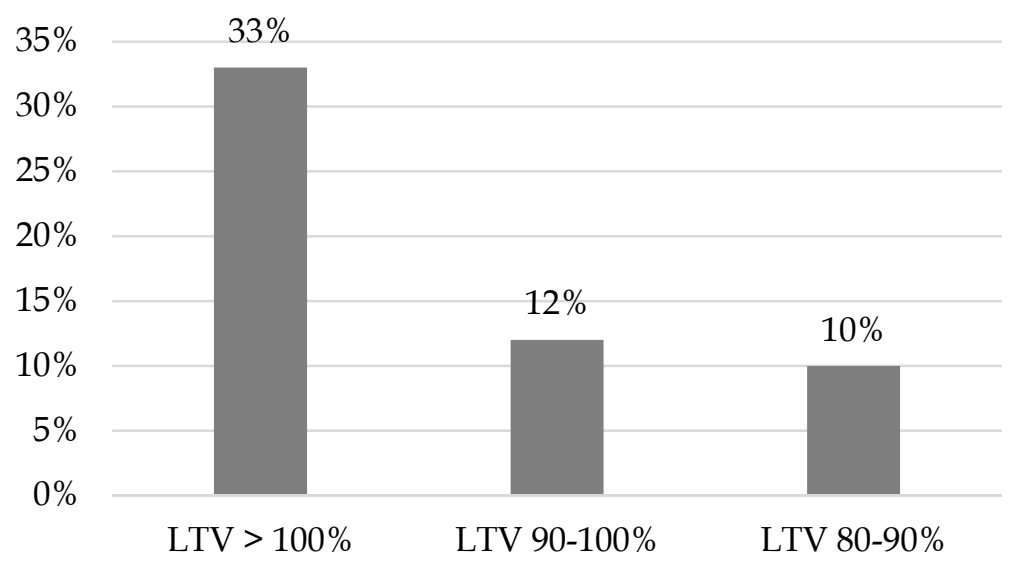

Figure 7. Mortgages with an LTV ratio in excess of $80 \%$ in the total value of the portfolio in 2012. Source: UKNF 2012.

Another important parameter used to assess loan portfolio quality, greatly affecting loan repayment receivables, is the loan-to-value ratio (LTV), as experience has it that LTV growth translates 
into higher credit risk (SIEMIŃSKA, RYMARZAK 2012). In Poland, the proportion of housing loans with a very high or even 100 per cent LTV, is relatively high (55 per cent), although the situation is going to change, as new, stricter KNF regulations took effect on 1 January 2014 (UKNF 2012) (Figure 7).

Table 1

Housing loans of various DTI ratios, granted in 2011-2012, as a proportion of loans in specific LTV groups (per cent)

\begin{tabular}{lccccccc}
\hline & \multicolumn{7}{c}{ DTI } \\
\cline { 2 - 8 } & $0-10 \%$ & $10-20 \%$ & $20-30 \%$ & $30-40 \%$ & $40-50 \%$ & $50-65 \%$ & $65-100 \%$ \\
\hline $\mathbf{L T V}$ & & & & $\mathbf{2 0 1 1}$ & & & \\
\hline $\mathbf{0 - 3 0} \%$ & 0.2 & 1.5 & 2.1 & 2.3 & 1.7 & 0.7 & 0.1 \\
\hline $\mathbf{3 0 - 5 0} \%$ & 0.4 & 1.6 & 3.1 & 3.1 & 3.1 & 1.5 & 0.1 \\
\hline $\mathbf{5 0 - 8 0} \%$ & 0.7 & 2.4 & 5.3 & 8.6 & 11.7 & 5.3 & 0.6 \\
\hline $\mathbf{8 0 - 1 0 0} \%$ & 0.2 & 1.5 & 5.1 & 9.9 & 10.8 & 7.8 & 0.4 \\
\hline $\mathbf{1 0 0} \%$ & 0 & 0.5 & 1 & 1.9 & 2.6 & 2 & 0.1 \\
\hline $\mathbf{L T V}$ & & & & $\mathbf{2 0 1 2}$ & & & \\
\hline $\mathbf{0 - 3 0} \%$ & 0.3 & 0.9 & 1.6 & 1.4 & 1.5 & 0.7 & 0.1 \\
\hline $\mathbf{3 0 - 5 0} \%$ & 0.2 & 1.4 & 2.8 & 3 & 4.2 & 1.3 & 0.1 \\
\hline $\mathbf{5 0 - 8 0} \%$ & 0.5 & 2.2 & 5.4 & 8.4 & 13.5 & 7.4 & 0.1 \\
\hline $\mathbf{8 0 - 1 0 0} \%$ & 0.3 & 1.9 & 4.9 & 9.3 & 11.6 & 8.9 & 0.2 \\
\hline $\mathbf{> 1 0 0} \%$ & 0.2 & 0.9 & 1.4 & 1.9 & 1.2 & 0.3 & 0 \\
\hline
\end{tabular}

Source: NBP XII 2013.

The last criterion in the analysis of the pattern of housing loans presented in this study is the currency. A peculiar phenomenon was the prevalence of foreign currency loans, especially Swiss franc-denominated ones, among the loans granted until 2008/2009, after which date this unfavorable and risky trend was reversed - under the influence of tighter KNF regulations (Figure 8 and Figure 9).

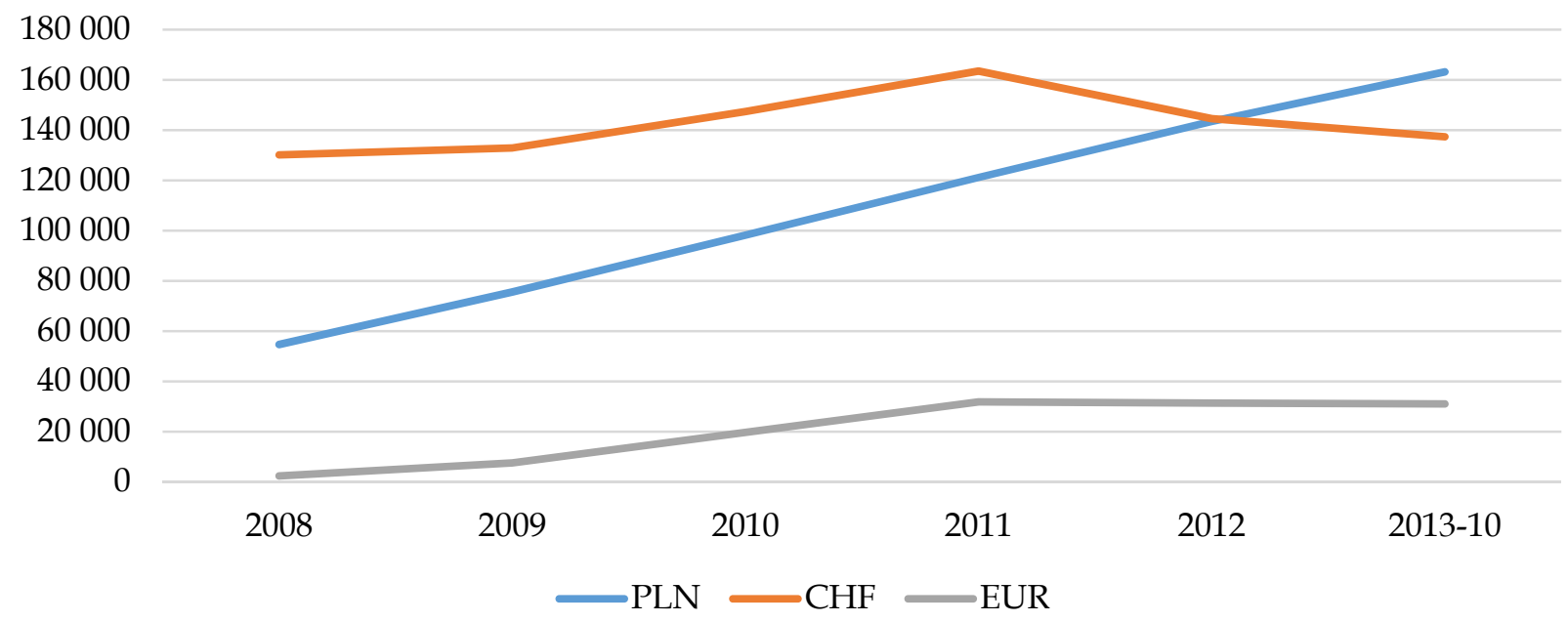

Figure 8. Currency breakdown of housing loans and their value (million). Source: UKNF XI 2013.

Today, most of the newly granted loans are denominated in the Polish currency (they accounted for 99.35 per cent of the total value of housing loans granted in Q3 2013, while 0.61 per cent were eurodenominated loans (ZBP 2013). The change in the composition of the housing loan portfolio makes it more secure, as the currency risk - particularly high when adverse currency fluctuations occur - is reduced. This was the situation of the Polish banking sector in the stormy period of 2008-2010, which resulted in a relatively high number of decisions to have the loan converted from foreign currencies to the Polish zloty. According to KNF, banks converted 6.5 thousand loans until 2010, with a total value of PLN 1.143 billion. Of these, 3.6 thousand loans amounting to PLN 811 million were impaired loans (KWAŚNIAK 2011). 


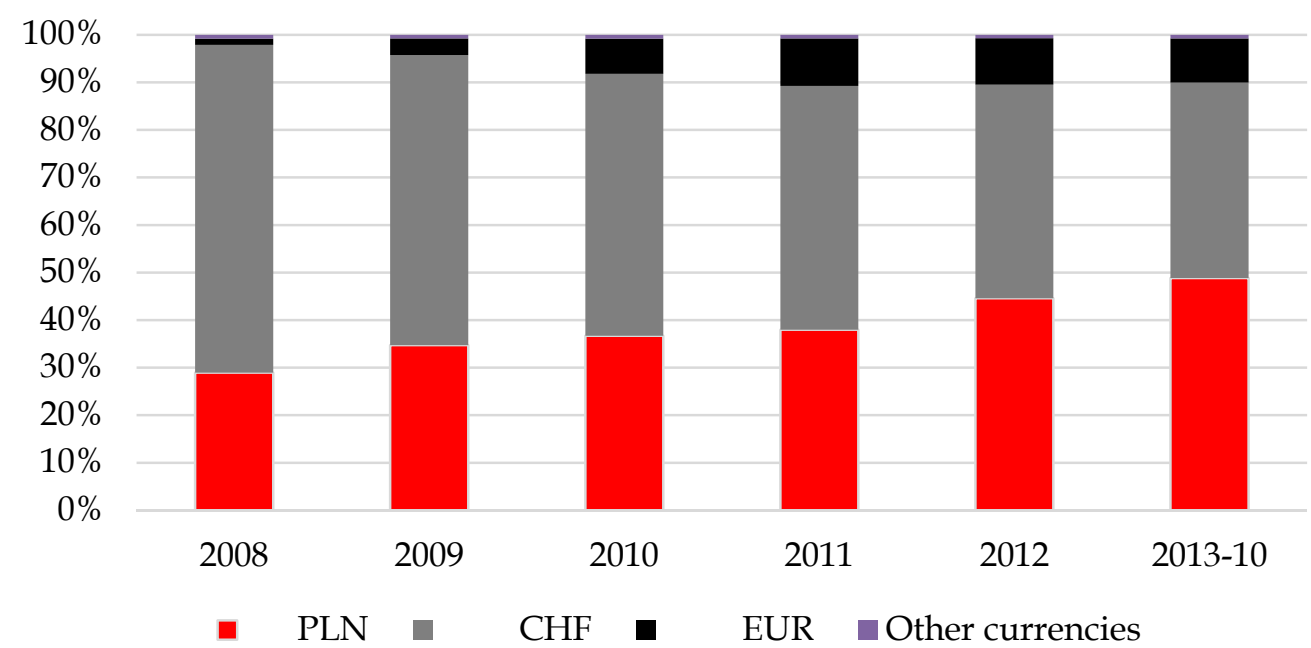

Figure 9. Changes in the currency breakdown of housing loans in 2008-2013. Source: UKNF XI 2013.

Regular analyses of the KNF, ZBP and BIK indicate that housing loan portfolios of banks in Poland were some of the relatively best repaid loans throughout the entire analyzed period. It has been demonstrated here, however, that the good quality of the housing loans results from their very short history; bank portfolios are chiefly filled with loans granted between 2005 and 2008, at a time when business was very good.

\section{Measures regulating housing market finance}

Experts say the rapid increment of the housing loan portfolio in the first decade of the 21st century was the combined effect of many factors, the most important among them being (KWAŚNIAK 2013):

1) the rising income of households,

2) foreign capital inflow,

3) lower bank rates,

4) clear easing of credit policies, including the credit rating of bank clients, which resulted from, among other causes, growing competition between banks,

5) ample offer of foreign currency loans,

6) high demand for housing on the one hand, coupled with a significant rise in property prices, on the other.

The Polish bank watchdog - KNF, taking into account the above factors which affect housing market finance and on the basis of previous experience, made a few modifications to its recommendations for the banking sector in the past several years. These recommendations are a regulatory tool aimed at the introduction and application of sound banking practices, primarily designed to reduce banking risks, credit risk included. A major regulation concerning financing the housing market is the so-called Recommendation S, which concerns sound practices in the management of mortgage-secured loan exposures. Its provisions were modified in 2011 and 2013. The recommendation deals with, in the first place, the risk involved in the portfolio of mortgage-secured loan exposures, in particular with:

1) limited liquidity in the property market, causing concern about its impact on this market and the effective disposal of collateral,

2) substandard property market databases,

3) lack of longer experience of property market participants,

4) difficulties in assessing the quality of mortgage loan portfolios and the banks' low effectiveness in enforcing their claims,

5) a limited range of bank procedures of monitoring collateral value and quality,

6) the absence of standards addressing the social considerations of enforcement and collateral disposal (KNF 2013).

The said Recommendation S modifications contributed to the changes in the pattern of the loan exposure portfolio, chiefly by reducing the proportion of foreign currency loans and by pressurizing 
banks to use more rigorous criteria in assessing their prospective clients' creditworthiness. The latter requirement, coupled with macroeconomic factors, led to a decline in the number of new housing loans (Figures 3, 9 and 10).

The 2013 amendments to the said Recommendation, in force as of 2014, concern mainly (KNF 2013):

1) exemption from Recommendation $S$ of housing loan exposures not secured by mortgage;

2) limitation of the availability of foreign currency loans to clients with regular income in the currency of the loan;

3) lifting of earlier DTI ceilings and allowing banks to decide their value;

4) gradual LTV ratio rectification for mortgage-secured loan exposures, which should not exceed:

- 95 per cent for exposures dating from before 31 December 2014

- 90 per cent for exposures dating from between 1 January and 31 December 2015,

- 85 per cent for exposures dating from between 1 January and 31 December 2016;

5) recommending a repayment period not longer than 25 years to retail loan applicants, and others.

The latter issue is directly connected with the borrower's minimum contribution requirement. Many banks, in fact, did not require any and loan offers could amount to 100-130 per cent of the value of mortgage collateral. In practice, the loan amount and requiring or not requiring a minimum contribution from the borrower, is the competitive edge of banks' loan offers.

Efforts made in the Polish banking market to build a bank risk monitoring system as well as databases of credit history of various client groups are easy to notice. Most recent data on the stability of the Polish banking sector show a greater loss-absorbing capacity of banks, as demonstrated by their improving capital adequacy ratios - comparable with those of banks in other EU member states. It is also important that, since the global crisis began in 2008, no bank in Poland found itself in a situation when recapitalization with public funds would be needed (NBP XII 2013). TIER 1 ratios are also above the raised (in mid-2013) value of 9 per cent, which is evidence of sound capital standing of the Polish banking sector (Table 2).

Table 2

Capital adequacy of the Polish banking sector (end of 2013)

\begin{tabular}{llll}
\hline & \multirow{2}{*}{ Years } & Capital Adequacy Ratio & TIER 1 Capital Ratio \\
\cline { 2 - 4 } & & in \% & \\
\hline $2010-03$ & 14.15 & 12.83 \\
\hline $2010-06$ & 13.36 & 12.06 \\
\hline $2010-12$ & 13.86 & 12.47 \\
\hline $2011-06$ & 13.74 & 12.37 \\
\hline $2011-12$ & 13.12 & 11.72 \\
\hline $2012-06$ & 13.63 & 12.26 \\
\hline $2012-12$ & 14.76 & 13.15 \\
\hline $2013-06$ & 15.25 & 13.78 \\
\hline $2013-09$ & 15.66 & 14.19 \\
\hline
\end{tabular}

Source: NBP XI 2013.

Table 3

Summary assessment of the Polish banking sector at the end of 2013

\begin{tabular}{|c|c|}
\hline Area of assessment & $\begin{array}{c}\text { Change in 2nd } \\
\text { half of } 2013\end{array}$ \\
\hline Current financial standing & no change \\
\hline Shock-absorbing capacity & improvement \\
\hline Current financial standing of non-bank financial entities & no change \\
\hline Prospects before the environment of the Polish economy & improvement \\
\hline Summary assessment of stability prospects of the national financial system & improvement \\
\hline
\end{tabular}

Source: NBP XII 2013. 
Stress-test verification of resistance to economic shocks shows a sufficient level of assets to absorb the effects of a possible major economic slowdown and to maintain a high-level capital adequacy (NBP XII 2013). Table 3 is a summary presentation of the situation in the Polish banking sector.

In conclusion of the discussion on housing market finance, two more regulations which affect the development of housing in Poland should be mentioned. One is the governmental program of support for families buying their own accommodation, known as "Family-owned accommodation" (Rodzina na swoim) (Ustawa o zmianie ustawy... 2011) operating between 2007 and 2012. The core of the program was a preferential loan, i.e. one on which the interest was refundable at the level of 50 per cent of interest payments calculated according to a reference rate, for a maximum period of eight years. The data in Table 4 show that, while the programme was not very popular in its early phase, it covered a large number of beneficiaries in subsequent years, to the total amount of nearly PLN 35 billion. In 2014, it was replaced by another governmental programme, "Housing for the Young" (Mieszkanie dla młodych).

Table 4

The volume of Family-owned Accommodation loans granted in 2007 - Q3 2013

\begin{tabular}{lrrrrrrr}
\hline $\begin{array}{c}\text { Family-owned accommodation } \\
\text { program }\end{array}$ & 2007 & 2008 & 2009 & 2010 & 2011 & 2012 & $\begin{array}{c}\text { Q3 } \\
2013^{*}\end{array}$ \\
\hline number of loans & 4001 & 6645 & 30882 & 43120 & 51328 & 45792 & 10585 \\
\hline value of the loans (PLN million) & 435 & 853 & 5418 & 8074 & 10249 & 7939 & 2003 \\
\hline
\end{tabular}

* Amounts disbursed throughout 2013 for loans granted on the basis of applications received before the end of 2002.

Source: BANK GOSPODARSTWA KRAJOWEGO 2013.

The other regulation seriously affecting the shape of the housing market is the so-called developer law, which took effect on 29 April 2012. It is meant to offer protection to the retail customer buying accommodation from a housing development company (Ustawa o ochronie praw... 2011). It binds the developer to give the prospective client reliable information on all technical, legal and financial parameters of the investment project that interest the client (in the developer's prospectus and the contract) and to make safe (through a bank escrow account) the money pre-paid by the client for such accommodation (SZREDER 2012). All the requirements contained in the legislation are designed to ensure that the developer's offer is presented to the client in a truthful manner, before the latter actually signs the contract, to prevent unfair practices that the former might use in selling projects. Such unfair practices were not uncommon in the Polish housing market before, as the quality of building and finishing, the location, or the financial terms were often considerably different from what had been declared or advertised by the developer. As a result, inter alia, of tighter legal requirements, fewer new housing projects are started by developers (Figure 1) and previously unsold apartments now sell more easily. This pushes prices up, at least in some locations, or at least stops their further downslide (Figure 2).

\section{Conclusions}

In the period studied here, the Polish housing market, like the markets of many other countries, went through a period of rapid and difficult systemic changes, resulting from the global economic downturn. Regulators and supervising authorities have been trying to acquire information on its sources, causes and course, and - as in the case of the previous crises, draw conclusions. As a result, prudential regulations, both national and supranational, are now in place, as well as many legal and financial solutions designed to make transactions more secure and transparent.

In Poland, changes concerning foreign currency loans are certainly of great importance for the borrowers. New regulations make it possible for the loan to be repaid in foreign currency, which is a positive development. On the other hand, the availability of foreign currency loans has been curtailed, which reduces the currency risk in the banking sector.

For borrowers, a negative effect of the crisis is, undoubtedly, the reduced availability of bank loans, resulting from greater formalization of credit procedures. Banks have adopted a rule under which credit decisions for larger loans have to be made by the head office, which above all uses the criterion of risk mitigation. Consequently, the effects of the regulation are not uniformly positive.

As a result, some financially weaker prospective borrowers may be excluded from the relatively 
safe and regulated banking sector, in which case the only option left for them are non-bank financial intermediaries (where the risk is much higher). Shadow banks, which gather deposits and operate on the basis of assets obtained from their clients, operate on the basis of separate legislation and are not subject to control by agencies of the state, established to supervise the security of the financial system. Their number, as well as the number of entities conducting operations without a permit required by the law, is rising from year to year.

Moreover, when loan support is more difficult to obtain, market demand is reduced and buyers' preferences shift to the smallest and least expensive accommodation (usually in city outskirts). This problem has an impact on developers as well; new construction projects are reduced or cancelled as developers try to match their offer to buyers' preferences. The great competition in the market forces them to price flexibly, especially long-unsold accommodation. Their situation in the market also deteriorated after the introduction of the developer legislation in 2012, which is designed to protect the buyer of accommodation, but imposes a number of costly obligations of formal or informative nature on the developer.

In Poland, housing demand fluctuations were, until the end of 2012, largely connected with the governmental programme supporting the purchase of an apartment - the Family-owned Accommodation Programme. As of 2014, they will be shaped by the new programme, Housing for the Young, under which the buyer's own contribution will be subsidised. Families in which a third child appears (whether born to the parents or adopted) will additionally be eligible for support in the earlier repayment of part of the loan principal. Furthermore, people who start building their own accommodation (an apartment or single-family house) will be eligible for a partial VAT refund on building materials.

\section{References}

BANK GOSPODARSTWA KRAJOWEGO 2013, Dane liczbowe programu Rodzina na Swoim, http://bgk.com.pl/storage/2864/Dane\%20liczbowe_do_30_czerwca_2013.pdf, 20.04.2014.

BHARDWAJ G., SENGUPTA R., 2012, Subprime mortgage design, Journal of Banking \& Finance, Vol. 36, Iss: 5, pp. 1503-1519.

BOLEAT M., COLES A., 2012, The mortgage market. Routledge, New York, NY.

BORGERSEN T. A., GREIBROKK J., 2012, Reflections on LTV, risk and incentives in mortgage markets, Journal of European Real Estate Research, Vol. 5 Iss: 3, pp. 199 - 210.

BRUECKNER J.K., CALEM P. S., NAKAMURA L. I., 2012, Subprime mortgages and the housing buble, Journal of Urban Economics, Vol. 71, Issue 2, pp. 230-243.

Coleman M., LaCour-LitTle M., VANDEll K.D., 2008, Subprime lending and the housing bubble: Tail wags dog? Journal of Housing Economics, Vol. 17, Iss: 4, pp. 272-290.

European Mortgage Federation 2013, Key Figures 2012, http://www.hypo.org/Content/default.asp?PageID=414, 20.04.2014.

EY 2014, Poland - the real state of real estate, The Polish Real Estate Guide, Edition 2014, http://www.ey.com/Publication/vwLUAssets/EY_Real_Estate_Guide_Book_2014/\$FILE/EY_Re al_Estate_Guide_Book_2014.pdf, 20.06.2014.

FORYŚ I., 2011, Społeczno-gospodarcze determinanty rozwoju rynku mieszkaniowego w Polsce, WNUS, Szczecin.

GAN C., LI Z., WANG W., KAO B., 2012, Credit scoring in mortgage lending: evidence from China, International Journal of Housing Markets and Analysis, Vol. 5 Iss: 4, pp. 334 - 350.

GROSSE R., 2012, Bank regulation, governance and the crisis: a behavioral finance view, Journal of Financial Regulation and Compliance, Vol. 20 Iss: 1, pp. $4-25$.

GUS 2013, Budownictwo mieszkaniowe $w$ latach 1989-III kwartat 2013 r., http://www.stat.gov.pl/gus/5840_781_PLK_HTML.htm, 20.04.2014.

KALLAKMAA-KAPSTA A., KOLBRE E., 2013, Estonian housing market: affordability problem and regulatory framework, International Journal of Housing Markets and Analysis, Vol. 6 Iss: 2, pp. 146 - 162.

KAU J. B., KeENAN D.C., LyUBimOv C., SLAWSON C., 2011, Subprime mortgage default, Journal of Urban Economics Volume 70, Iss: 2-3, pp. 75-87.

KNF 2013, Rekomendacja S dotyczaca dobrych praktyk w zakresie zarzadzania ekspozycjami kredytowymi finansujacymi nieruchomości oraz zabezpieczonymi hipotecznie, http://www.knf.gov.pl/Images/Rekomendacja_S_18-01-2011_tcm75-25296.pdf, 20.04.2014. 
KWAŚNIAK W., 2011, Poprawa bezpieczeństwa rynku kredytów mieszkaniowych w aspekcie polityki nadzorczej, http:/ / www.knf.gov.pl/Images/Poprawa_bezpieczenstwa_rynku_kredytow\%20mieszkaniowych _tcm75-28542.pdf, 20.04.2014.

KWAŚNIAK W., 2013, Finansowanie budownictwa mieszkaniowego $w$ Polsce, http://www.senat.gov.pl/gfx/senat/userfiles/_public/k8/komisje/2013/kbfp/prezentacje/097_ 3a.pdf, 20.04.2014.

LIS P., 2012, Wahania cykliczne rynków mieszkaniowych aspekty teoretyczne i praktyczne, Wydawnictwo Adam Marszałek, Torun.

NBP 2012, Raport o sytuacji na rynku nieruchomości mieszkaniowych i komercyjnych w Polsce w 2011, http://www.nbp.pl/home.aspx?f=/publikacje/rynek_nieruchomosci/index1.html, 20.04.2014.

NBP 2013, Baza cen nieruchomości mieszkaniowych (III kw. 2006-III kw. 2013), www.nbp.pl/publikacje/rynek_nieruchomosci/ceny_mieszkan.xls, 20.04.2014.

NBP X 2013, Sytuacja na rynku kredytowym. Wyniki ankiety do przewodniczących komitetów kredytowych, http://nbp.pl/systemfinansowy/rynek_kredytowy_2013_4.pdf, 20.04.2014.

NBP XI 2013, Adekwatność kapitałowa banków, http://www.nbp.pl/home.aspx?f=/statystyka/pieniezna_i_bankowa/adekwatnosc_kapitalowa.h tml, 20.04.2014.

NBP XII 2013, Raport o stabilności systemu finansowego, http://nbp.pl/systemfinansowy/rsf122013.pdf, 20.04.2014.

NYKIEL L., 2011, Demograficzne uwarunkowania rozwoju mieszkalnictwa i rynku mieszkaniowego, Studia i Materiały Towarzystwa Naukowego Nieruchomości, Vol. 19, No. 3, pp. 60-72.

SANDERS A., 2008, The subprime crisis and its role in the financial crisis, Journal of Housing Economics, Vol. 17, Iss: 4, pp. 254-261.

SIEMIŃSKA E., 2011, Locating Capital in the Real Estate Market, in SIEMIŃSKA E. (ed.), Investment on the Real Estate Market. Wydawnictwo Naukowe Uniwersytetu Mikołaja Kopernika, Torun, pp. 7-41.

SIEMIŃSKA E., 2012, The Residential Real Estate Market in Poland, Journal Business: Theory and Practice, Vol. 13 No. 1, pp. 43-49.

SIEMIŃSKA E., 2013, Ryzyka inwestowania i finansowania na rynku nieruchomości w kontekście etyki $i$ społecznej odpowiedzialności. Wydawnictwo UMK, Torun.

SIEMIŃSKA E., RYMARZAK M., 2012, Bank Risk in Real Estate Finances in Poland, paper presented at the FIG Working Week 2012, Knowing to manage the territory, protect the environment, evaluate the cultural heritage, Rome, Italy, 6-10 May 2012, http:/ / www.fig.net/pub/fig2012/papers/ts05c/TS05C_sieminska__rymarzak_5495.pdf, 20.04.2014.

SZREDER J., 2012, Próba oceny wpływu nowej ustawy deweloperskiej na rynek nieruchomości w Polsce, Studia i Materiały Towarzystwa Naukowego Nieruchomości, Vol. 20, No. 3, pp. 273-283.

Trojanek M. (ed.), 2013, Ekonomiczne uwarunkowania decyzji na rynku nieruchomości wybrane problemy, Uniwersytet Ekonomiczny w Poznaniu, Poznań.

UKNF 2011, Wyniki ankiety na temat kredytów mieszkaniowych gospodarstw domowych z dn. 7.09.2011, http:/ / www.knf.gov.pl/Images/KNF_kredyty_mieszkaniowe_7-09-2011_tcm75-27556.pdf, 20.04.2014.

UKNF 2012, Nowelizacja Rekomendacji S. Główne cele, kierunki i uzasadnienie zmian, http://www.knf.gov.pl/Images/Prezentacja_reko_S_tcm75-32877.pdf, 20.04.2014.

UKNF 2013A, Raport o sytuacji banków $w 2012$ roku, http:// www.knf.gov.pl/Images/RAPORT_O_SYTUACJI_BANKOW_w_2012_pdf_tcm7534744.pdf, 20.04.2014.

UKNF 2013B, Raport o sytuacji banków w I pótroczu 2013 roku, http://www.knf.gov.pl/Images/Raport_o_sytuacji_bankow_w_I_polroczu_2013_tcm7535848.pdf, 20.04.2014.

UKNF 2013C, Informacja o sytuacji banków w okresie I-IX $2013 \quad$ r. http://www.knf.gov.pl/Images/Banki_III_2013_raport_tcm75-36554.pdf, 20.04.2014.

UKNF IX 2012, Dane miesięczne dot. sektora bankowego, koniec września 2012 r., http:/ / bs.net.pl/rankingiwyniki-finansowe-sektora/knf-dane-sektora-bankowego-na-wrzesien-2012-r, 20.04.2014. 
UKNF XI 2013, Dane miesięczne sektora bankowego, http://www.knf.gov.pl/opracowania/sektor_bankowy/dane_o_rynku/Dane_miesieczne.html, 20.04.2014.

Ustawa z dnia 15 lipca 2011 r. o zmianie ustawy o finansowym wsparciu rodzin w nabywaniu wtasnego mieszkania oraz niektórych innych ustaw, Dz. U. 2011 nr 168, poz. 1006.

Ustawa z dnia 16 września 2011 r. o ochronie praw nabywcy lokalu mieszkalnego lub domu jednorodzinnego, Dz. U. $2011 \mathrm{nr}$ 232, poz. 1377.

ZBP 2013, Ogólnopolski raport o kredytach mieszkaniowych $i$ cenach transakcyjnych nieruchomości, http://zbp.pl/public/repozytorium/wydarzenia/dokumenty/listopad_2013/konferencja_praso wa/Raport_AMRON-SARFiN_Nr_3_2013_Pl_skrot.pdf, 20.04.2014. 